Azis, Nining Nurbianti K.

\title{
MENINGKATKAN PRESTASI BELAJAR SISWA SMP PADA MATERI BANGUN RUANG SISI DATAR MELALUI PENDEKATAN CONTEXTUAL TEACHING AND LEARNING
}

\author{
Azis ${ }^{1)}$, Nining Nurbianti $\mathrm{K}^{2)}$ \\ Dosen Pendidikan Matematika FKIP Unidayan Baubau ${ }^{1)}$ \\ Mahasiswa Pendidikan Matematika FKIP Unidayan Baubau ${ }^{2)}$ \\ azis_nasam@yahoo.com ${ }^{1)}$,ddnining@gmail.com ${ }^{2)}$
}

\begin{abstract}
Abstrak
Tujuan penelitian ini adalah untuk meningkatkan prestasi belajar siswa kelas VIII-F SMP Negeri 3 Baubau pada materi bangun ruang sisi datar melalui pendekatan contexstual teaching and learning. Penelitian ini adalah penelitian tindakan kelas dengan subyek penelitian siswa kelas VIII-F SMP Negeri 3 Baubau yang jumlahnya 18 orang. Prosedur penelitian setiap siklus terdiri dari 4 tahap yaitu pendahuluan, tindakan, observasi/evaluasi, dan refleksi. Data dalam penelitian ini dikumpulkan dengan menggunakan instrumen penelitian berupa pedoman observasi, tes hasil belajar matematika, dan refleksi. Berdasarkan hasil tes awal, nilai rata-rata mencapai 50 dan ketuntasan klasikal sebesar 33,33\%. Pada siklus I, nilai rata-rata sebesar 52,5 dengan ketuntasan belajar klasikal sebesar 50\%. Pada siklus II, nilai rata-rata sebesar 79,44 dengan ketuntasan belajar klasikal sebesar 100\%. Dengan demikian dapat disimpulkan bahwa pembelajaran matematika dengan menggunakan pendekatan contextual teaching and learning dapat meningkatkan prestasi belajar pada siswa kelas VIII-F SMP Negeri 3 Baubau.
\end{abstract}

Kata kunci: prestasi belajar, bangun ruang, sisi datar, contexstual teaching and learning

\begin{abstract}
Objective of this research was to improve students' learning achievement at class VIII-F of SMP Negeri 3 Baubau on learning topic of polyhedral through contextual teaching and learning approach. This research was classroom action research with research subject was class VIII-F students of SMP Negeri 3 Baubau with had 18 students. Research procedure in every cycle consisted of four steps: introduction, action, observation/evaluation, and reflection. Data in this research were collected with using research instruments, such as observation manual, mathematics learning outcome test, and reflection. Based on pretest outcome, mean score achieved 50 and classical completeness was $33.33 \%$. In cycle II, the mean score was 79.44 with the classical learning completeness was 100\%. Therefore, it can be concluded that mathematics learning with using contextual teaching and learning approach can improve students learning achievement at class VIII-F students of SMP Negeri 3 Baubau.
\end{abstract}

Keywords: learning achievement, polyhedral, contextual teaching and learning

\section{PENDAHULUAN}

Salah satu masalah yang dihadapi dalam pendidikan sebagai salah satu komponen penting dalam meningkatkan kualitas sumberdaya manusia adalah lemahnya proses pembelajaran. Untuk mengatasi permasalahan tersebut pemerintah dalam hal ini Kementerian Pendidikan Dasar, Menengah, dan Kebudayaan telah melakukan berbagai upaya dalam meningkatkan kualitas pendidikan.Hal ini dapat dilihat dari berbagai kebijakan yang ditempuh, yakni perubahan dan perbaikan kurikulum, pengalokasian anggaran pendidikan, penataran guru-guru, dan lain-lain dalam rangka peningkatan kualitas pendidikan.

Disamping banyaknya upaya-upaya yang dilakukan pemerintah tersebut, hal yang tidak bisa dipungkiri bahwa hal yang terpenting dan paling utama untuk meningkatkan kualitas pendidikan dalam hal ini prestasi belajar siswa (peserta didik) adalah pelaksanaan proses pembelajaran di sekolah. Oleh karena itu sekolah sebagai komponen utama pendidikan perlu mengelola proses pembelajaran seefektif dan seoptimal mungkin. Untuk menciptakan pembelajaran yang efektif dan optimal maka pelaksanaan pembelajaran di sekolah harus sesuai dengan prinsip-prinsip Kegiatan Belajar Mengajar (KBM) yang beberapa diantaranya adalah kegiatan berpusat pada siswa, belajar melalui berbuat, dan belajar mandiri dan bekerjasama.Sejalan dengan prinsip kegiatan belajar mengajar tersebut maka kegiatan pembelajaran diharapkan tidak hanya berfokus 
Azis, Nining Nurbianti K.

pada guru, tetapi bagaimana mengaktifkan siswa dalam belajarnya sebagaimana yang dikehendaki dalam Kurikulum Tingkat Satuan Pendidikan (KTSP).

Pembelajaran yang dikehendaki oleh kurikulum khususnya KTSP adalah pembelajaran yang diarahkan pada kegiatan-kegiatan yang mendorong siswa belajar aktif baik fisik, mental, maupun sosial untuk memahami konsep-konsep dalam pembelajaran tersebut. Tetapi pada kenyataannya pada proses pembelajaran guru masih menjadi pusat perhatian siswa, dalam hal ini siswa tidak berperan aktif saat proses pembelajaran berlangsung. Sehingga perlu diterapkannya pembelajaran yang tidak hanya mentransfer pengetahuan kepada siswa, tetapi juga memfasilitasi siswa aktif membentuk pengetahuan mereka sendiri serta memberdayakan mereka untuk memecahkan masalah-masalah yang dihadapinya. Oleh karena itu seorang guru dituntut untuk menggunakan pendekatan yang melibatkan siswa dalam belajar yang dapat mengaktifkan interaksi antara siswa dan guru, siswa dan siswa, serta siswa dan bahan belajarnya. Prinsip-prinsip tersebutlah yang semestinya menjadi pertimbangan guru dalam memilih model, metode, atau pendekatan yang akan diterapkan dalam proses belajar mengajar di kelas, termasuk pada mata pelajaran Matematika.

Pada hakekatnya pembelajaran matematika yang diberikan pada siswa SMP mudah dan sederhana yang merupakan pembelajaran tentang penerapan konsep-konsep lanjutan dari pembelajaran yang didapatkan saat duduk di Sekolah Dasar. Tetapi tidaklah boleh dipandang sepele, karena materi matematika SMP merupakan studi objekyang memuat tentang konsep-konsep lanjutan yang penting.Konsepkonsep dalam matematika merupakan suatu rangkaian sebab-akibat, suatu konsep disusun berdasarkan konsep-konsep sebelumnya dan akan menjadi dasar bagi konsep-konsep selanjutnya (Antonius, 2006, p.1).

Pendekatan kontekstual konsep pembelajarannya guru menghadirkan situasi dunia nyata ke dalam kelas dan mendorong siswa membuat hubungan antara pengetahuan yang dimilikinya dengan penerapannya dalam kehidupan mereka sebagai anggota keluarga dan masyarakat. Pendekatan kontekstual, hasil pembelajaran diharapkan lebih bermakna bagi siswa. Proses pembelajaran berlangsung alamiah dalam bentuk kegiatan siswa bekerja dan mengalami, bukan transfer pengetahuan dari guru ke siswa. Dalam konteks itu, siswa perlu mengerti apa makna belajar, apa manfaatnya, dalam status apa mereka, dan bagaimana mencapainya. Mereka sadar bahwa yang mareka pelajari berguna bagi hidupnya nanti. Dengan begitu mereka memposisikan sebagai diri sendiri yang memerlukan suatu bekal untuk hidupnya nanti. Dalam upaya itu, mereka memerlukan guru sebagai pengarah dan pembimbing (Nurhadi, 2003, p.4). Pendekatan ini juga dilakukan sesuai dengan kesiapan intelektual anak, sehingga penerapan pendekatan ini harus tersusun menurut urutan logis tingkat kemampuan pengalaman siswa (Aisyah, 2006, p.3-4).

Berdasarkan uraian di atas, peneliti tertarik melakukan penelitian tindakan kelas dengan judul "Meningkatkan Prestasi Belajar Siswa Kelas VIII-F SMP Negeri 3 Baubau pada MateriBangun Ruang Sisi Datar melalui Pendekatan Contextual Teaching and Learning (CTL)."

Berdasarkan latar belakang masalah di atas maka masalah yang akan diteliti dapat dibatasi pada pokok bahasan Bangun Ruang Sisi Datar, sub pokok bahasan prisma dan limas yang meliputi aspek pemahaman konsep. Berdasarkan uraian pada pembatasan masalah diatas maka rumusan masalah dalam penelitian ini adalah "Apakah prestasi belajar siswa kelas VIII-F SMP Negeri 3 Baubau pada materiBangun Ruang Sisi Datardapat ditingkatkan melalui pendekatan Contextual Teaching and Learning (CTL)?”. Adapun tujuan dari penelitian ini adalah untuk meningkatkan prestasi belajar siswa kelas VIII-F SMP Negeri 3 Baubau pada materi Bangun Ruang Sisi Datar melalui pendekatan Contextual Teaching and Learning (CTL).

Seperti yang diketahui bersama saat ini guru dalam menyajikan materi pembelajaran masih menggunakan model pembelajaran tradisional (konvensional). Untuk mengatasi permasalahan di atas maka perlu adanya pendekatan pembelajaran yang tepat. Salah satunya adalah dengan pendekatan kontekstual. Pendekatan ini dipilih karena sesuai dengan karakteristik berpikir siswa dalam memahami materi tentang bangun ruang sisi datar pada aspek pemahaman konsep, penerapan, dan pemecahan masalah yang dikaitkan langsung dengan dunia nyata siswa. Ada tujuh komponen utama pembelajaran yang mendasari penerapan pendekatan kontekstual di kelas. Ketujuh komponen utama itu adalah konstruktivisme (Constructivism), bertanya (Questioning), menemukan (Inquiry), masyarakat belajar (Learning Community), pemodelan (Modeling), refleksi (Reflection), dan penilaian 
Azis, Nining Nurbianti K.

sebenarnya (Authentic Assessment). Dalam kelas dikatakan menggunakan pendekekatan kontekstual jika menerapkan ketujuh komponen tersebut dalam pembelajarannya.

Dalam penerapan pendekatan kontekstual ini juga menggunakan tahapan pembelajaran berbasis masalah.Sehingga melalui pendekatan kontekstual dapat melatih siswa untuk mampu menggunakan berbagai konsep, prinsip dan keterampilan matematika untuk memecahkan masalah matematika dalam kehidupan seharihari. Melalui pendekatan ini bukan hanya hasil yang dilihat tetapi proses pembelajaran yang diharapkan agar siswa benar-benar memahami apa yang dipelajari.

Dengan dasar inilah sehingga peneliti menjadikan sebagai landasan berpikir bahwa dengan pendekatan kontekstual dapat membantu siswa meningkatkan prestasi belajar dalam memahami tentang materi bangun ruang sisi datar.

\section{METODE PENELITIAN}

\section{Pendekatan dan Jenis Penelitian}

Pendekatan yang digunakan pada penelitian ini adalah pendekatan kualitatif dan jenis penelitian ini adalah penelitian tindakan kelas (PTK). Penelitian kualitatif adalah penelitian yang bermaksud untuk memahami fenomena tentang apa yang dialami oleh subjek penelitian misalnya perilaku, persepsi, motivasi, tindakan, dan lain-lain. Karakteristik dari penelitian tindakan kelas adalah (1) penelitian berawal dari keseriusan guru akan kinerjanya, (2) metode utama adalah refleksi diri, bersifat agak longgar tetapi tetap mengikuti kaidah-kaidah penelitian, (3) fokus penelitian berupa kegiatan pembelajaran, dan (4) tujuannya adalah memperbaiki pembelajaran.

\section{Waktu dan Tempat Penelitian}

Penelitian ini dilaksanakan pada semester genap tahun ajaran 2015/2016 di SMP Negeri 3 Baubau dari tanggal 13 April 2016 sampai tanggal 19 Mei 2016.

\section{Subjek Penelitian}

Adapun subjek dalam penelitian ini adalah siswa kelas VIII-F SMP Negeri 3 Baubau dengan alasan prestasi belajar di kelas VIII-F masih rendah dibanding dengan kelas-kelas yang lain.

\section{Instrumen Penelitian dan Teknik Pengumpulan Data}

Dalam penelitian ini digunakan instrumen sebagai berikut: 1) Lembar pengamatan, yaitu berupa catatan tentang aktivitas siswa dan guru dalam mengikuti pelajaran yang bertujuan sebagai pedoman untuk menentukan tindakan berikutnya; 2) Tes belajar, yaitu tes yang diberikan kepada siswa setelah diadakan tindakan setiap siklus; dan 3) Data tentang refleksi diri yang diambil dengan menggunakan jurnal.

Adapun teknik pengumpulan data adalah sebagai berikut: 1) Data mengenai kondisi kegiatan belajar mengajar dan perubahan sikap siswa dan guru dikumpulkan melalui pengamatan pada saat kegiatan pembelajaran berlangsung; 2) Data mengenai prestasi belajar siswa dikumpulkan dengan menggunakan tes pada setiap akhir siklus; dan 3) Jurnal refleksi diri.

\section{Prosedur Penelitian}

Penelitian ini adalah Penelitian Tindakan Kelas (PTK) yang pelaksanaanya tiap siklus dilaksanakan sesuai perubahan yang ingin dicapai. Sebelum dilaksanakan tindakan, terlebih dahulu diberikan tes awal dengan maksud untuk mengetahui kemampuan awal siswa. Kemudian setiap siklus terdiri 4 tahapyaitu: (1) tahap pendahuluan (pratindakan), (2)tahap tindakan, (3) observasi/evaluasi, dan (4) refleksi (Arikunto, 2007, p.16).

Pelaksanaan siklus berdasarkan pada faktorfaktor yang akan diteliti yang meliputi: 1) Faktor input, yang akan diselidiki adalah kehadiran siswa, perubahan sikap siswa, dan keaktifan siswa dalam proses belajar mengajar matematika; 2) Faktor proses, yang akan diselidiki adalah keterlaksanaan proses belajar mengajar yang antara lain interaksi antara guru dan siswa serta interaksi antara siswa dan siswa selama proses pembelajaran berlangsung; dan 3) Faktor output, yang akan diselidiki adalah hasil belajar matematika siswa yang diperoleh dari tes akhir pada setiap siklus setelah diterapkan model pembelajaran Contextual Teaching and Learning (CTL).

Secara rinci, prosedur penelitian tindakan kelas ini dapat dijabarkan sebagai berikut:

Tahap Pendahuluan

Kegiatan yang dilakukan pada tahap ini adalah sebagai berikut: 1) Membicarakan persiapan tindakan dalam waktu pelaksanaan tindakan yang dilakukan pada pertemuan awal 
Azis, Nining Nurbianti K.

dengan guru bidang studi pendidikan matematika; 2) Membuat Rencana Pelaksanaan Pembelajaran (RPP); 3) Membuat Lembar Kerja Siswa (LKS); 4) Membuat lembar observasi untuk aktifitas siswa selama berlangsungnya proses belajar mengajar di kelas pada pelaksanaan tindakan setiap siklus; 5) Membuat tes hasil belajar matematika; dan 6) Mempelajari bahan yang akan diajarkan dari berbagai sumber.

\section{TahapTindakan}

1) Melaksanakan proses kegiatan belajar mengajar dengan mengacu pada RPP yang telah dibuat; 2) Peneliti mengatur segala hal yang memudahkan saat pelaksanaan penelitian; 3) Pada awal pertemuan, guru menjelaskan materi sesuai dengan tindakan pembelajaran yang telah direncanakan sebelumnya pada pokok bahasan Bangun Ruang Sisi Datar, sub pokok bahasan prisma dan limas; 4) Selama proses belajar, para siswa diawasi, dikontrol, dan diarahkan, serta diberikan bimbingan secara langsung pada siswa yang mengalami kesulitan; dan 5) Lembar jawaban dari individu diperiksa kemudian dikembalikan.

\section{Observasi/evaluasi}

Pada tahap ini dilaksanakan proses observasi terhadap pelaksanaan tindakan setiap siklus dengan menggunakan lembar observasi yang telah dibuat kemudian melaksanakan evaluasi dengan mengadakan tes akhir pada setiap siklus.

\section{Refleksi}

Pada tahap ini, hasil yang diperoleh dalam tahap evaluasi dikumpulkan dan dianalisis oleh guru dan peneliti.Dari hasil analisis tersebut dilakukan refleksi. Kemudian dari hasil tersebut akan dilihat apakah memenuhi target yang diterapkan pada indikator kerja, jika pada siklus I belum memenuhi target maka penelitian akan dilanjutkan pada siklus II dan kelemahankelemahan/kekurangan-kekurangan yang terjadi pada siklus diperbaiki sehingga hasil yang dicapai pada siklus berikutnya bisa sesuai dengan harapan peneliti. Skema pelaksanaan penelitian ini seperti Gambar 1.

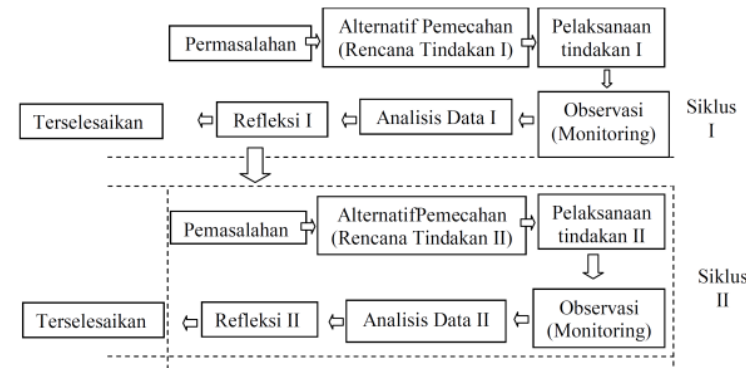

Gambar 1. Rancangan dan model Penelitian Tindakan Kelas (PTK) Diadaptasi dari (Anonim, 1999, p.27)

\section{Teknik Analisis Data}

Data yang diperoleh pada setiap kegiatan observasi dari setiap siklus, berupa hasil tes siswa, akan dianalisis secara kualitatif. Analisis kualitatif dilakukan dengan metode alur yaitu data dianalisis sejak tindakan pembelajaran dilaksanakan, dikembangkan selama proses pembelajaran. Menurut Miles dan Hubberman (Sutama, 2000, p.104), alur yang dilalui meliputi reduksi data, penyajian data dan penarikan kesimpulan atau verifikasi.

\section{Redukksi Data}

Pada tahap reduksi data ini, hal yang dilakukan yaitu menyeleksi, menyederhanakan, memfokuskan pada hal-hal penting, dan menghapus data yang tidak terpola dari hasil dan jurnal harian.

\section{Penyajian Data}

Pada langkah ini peneliti menampilkan data mengenai prestasi belajar siswa, efektifitas kegiatan guru, dan efektifitas belajar siswa.

Penarikan Kesimpulan

Dalam kegiatan ini ditarik kesimpulan berdasarkan hasil tindakan penelitian yang akan dilakukan. Kesimpulan yang diambil merupakan dasar bagi pelaksanaan siklus berikutnya dan perlu tidaknya siklus II dilanjutkan. Dalam kegiatan ini juga akan diperoleh jawaban atas permasalahan yang ditemukan pada awal pelaksanaan.

Keberhasilan penelitian ini, dilihat dari dua segi, yaitu dari segi proses dan dari segi prestasi (nilai) siswa. Dari segi proses, tindakan dikategorikan berhasil bila minimal $80 \%$ proses pelaksanaan tindakan telah sesuai dengan skenario pembelajaran. Dari segi hasil, tindakan dikategorikan berhasil bila siswa memperoleh nilai $\geq 60$. 
Azis, Nining Nurbianti K.

\section{HASIL PENELITIAN DAN PEMBAHASAN}

\section{Hasil Penelitian}

Pada bagian ini akan dibahas hasil-hasil penelitian setelah pelaksanaan pendekatan Contextual Teaching and Learning (CTL), prestasi belajar siswa kelas VIII-F SMP Negeri 3 Baubau pada materi bangun ruang sisi datar dapat ditingkatkan. Sebelum melaksanakan penelitian, peneliti melakukan koordinasi dengan Kepala Sekolah. Koordinasi berlangsung pada tanggal 13April 2016 membicarakan tentang waktu dan persiapan yang diperlukan dalam melakukan penelitian. Peneliti juga menyampaikan rencana tes awal yang akan dilakukan. Pada pertemuan tersebut Kepala Sekolah memberikan izin pelaksanaan penelitian dan mempersilahkan berkonsultasi langsung dengan guru kelas VIII-F dalam menetapkan jadwal tes awal dan rencana penelitian.Tes awal dilaksanakan pada tanggal 20April 2016 dengan maksud untuk mengetahui kemampuan awal siswa dalam memahami materi matematika khususnya pada materi pokok pembahasan bangun ruang sisi datar untuk diterapkan pada permasalahan-permasalahan sehari-hari. Kemampuan awal tersebut digunakan sebagai patokan dalam pelaksanaan tindakan siklus I. Soal-soal tes awal dibuat dari materi yang berkaitan dengan materi yang akan diajarkan.

Berdasarkan hasil tes awal, dari 18 siswa yang mengikuti ujian sebanyak 6 siswa yang memperoleh nilai $\geq 60$ dan yang memperoleh nilai $<60$ sebanyak 12 sisiwa dengan rata-rata keseluruhan mencapai 50 dan ketuntasan klasikal sebesar 33,33\%. Kemampuan awal tertinggi 75, sedangkan kemampuan terendahnya adalah 20 . Tampak bahwa rata-rata kemampuan awalnya masih dibawah batas ketuntasan yaitu 60 . Hal ini menunjukan bahwa masih banyak siswa yang belum menguasai konsep matematika (pembahasan bangun ruang sisi datar).

Tabel 1. Rekapitulasi Prestasi Belajar SiswaPada Tes Awal

\begin{tabular}{cccc}
\hline Indikator & Kategori & $\begin{array}{c}\text { Banyak } \\
\text { Siswa }\end{array}$ & Persentase \\
\hline $\mathrm{N} \geq 60$ & Tuntas & 6 & $33,33 \%$ \\
$\mathrm{~N}<60$ & $\begin{array}{c}\text { Tidak } \\
\text { tuntas }\end{array}$ & 12 & $66,67 \%$ \\
\hline
\end{tabular}

Siklus I

\section{Tahap Pendahuluan}

Sebelum melakukan penelitian terlalu jauh hal yang pertama yang dilakukan oleh guru adalah bagaimana merencanakan proses pembelajaran Contextual Teaching and Learning (CTL). Dalam hal ini bagaimana peneliti melakukan telaah terhadap kurikulum, khususnya kurikulum Sekolah Menengah Pertama.Hal tersebut dilakukan untuk mencapai standar kompetensi yang ingin dicapai pada materi belajar bangun ruang sisi datar.Hal-hal yang dipersiapkan pada saat pelaksanaan tindakan siklus Itersebut adalah sebagai berikut: 1) Menyiapkan rencana pembelajaran untuk pelaksanaan tindakan siklus I; 2) Menyiapkan lembar pengamatan (observasi) terhadap guru dan siswa; 3) Menyiapkan alat bantu mengajar; 4) Menyiapkan lembar kertas kerja; dan 5) Menyiapkan alat evaluasi.

Dalam proses pembelajaran metode CTL berlangsung, siswa dibagi dalam beberapa kelompok untuk saling berdiskusi dalam menyelesaikan soal yang telah disediakan oleh peneliti (guru PTK) dan diharapkan setiap siswa aktif dan kreatif untuk mendapatkan hasil yang terbaik. Pembagian kelompok dibagi sesuai dengan tingkat kemampuan siswa yang berbedabeda.

\section{Tahap Tindakan}

\section{$\underline{\text { Pertemuan } 1}$}

Pembelajaran tindakan pertemuan I dilaksanakan pada hari Rabu 27 April 2016 dan materi yang diajarkan yaitu unsur-unsur, sifatsifat prisma dan limas serta jaring-jaringnya.Pada saat guru melakukan pembelajaran di dalam kelas, guru terlebih dahulu membacakan langkahlangkah pembelajaran pendekatan Contextual Teaching and Learning (CTL) yaitu: 1) Kembangkan pemikiran bahwa anak akan belajar lebih bermakna dengan cara bekerja sendiri, menemukan sendiri, dan mengkostruksi sendiri pengetahuan dan keterampilan barunya; 2) Laksanakan sejauh mungkin kegiatan inquiry untuk semua topik; 3) Kembangkan sifat ingin tahu siswa dengan bertanya; 4) Ciptakan 'masyarakat belajar' (belajar dalam kelompokkelompok); 5) Hadirkan 'model' sebagai contoh pembelajaran; 6) Lakukan refleksi di akhir pertemuan; dan 7) Lakukan penilaian yang sebenarnya dengan berbagai cara. 
Azis, Nining Nurbianti K.

Peneliti (guru PTK) memulai proses pembelajaran dengan melaksanakan tindakan pendahuluan yakni menginformasikan materi yang dibahas (bangun ruang sisi datar), menyampaikan tujuan pembelajaran dan kompetensi dasar yang ingin dicapai serta menginformasikan kemampuan prasyarat yang dimiliki siswa. Pada pendahuluan ini peneliti (guru PTK) memberikan motivasi kepada siswa yang berhubungan dengan materi yang akan dibahas. Setelah dilakukan kegiatan pendahuluan peneliti (guru PTK) melaksanakan kegiatan inti yang sesuai dengan tujuan pembelajaran pada siklus I pertemuan I padalampiran 5 halaman 7889. Pembelajaran ini diikuti oleh 18 siswa dan dilaksanakan dengan cara diskusi kelompok. Kelompok pembelajarannya terdiri dari 4 kelompok yakni 2 kelompok terdiri dari 5 siswa dan 2 kelompok terdiri dari 4 siswa.

Pada kegiatan inti ini, peneliti (guru PTK) mengingatkan kembali tentang bangun datar kemudian memancing rasa ingin tahu siswa dengan pertanyaan, apa saja benda-benda di sekitar kita yang berbentuk prisma dan limas.Setelah itu peneliti (guru PTK) membagikan siswa Lembar Kerja Siswa (LKS) mengenai bagian-bagian, sifat-sifat, serta jaringjaring prisma dan limas. Siswa mengerjakan LKS secara berkelompok. Pada saat pembelajaran berlangsung jika ada siswa yang mengalami kesulitan maka peneliti (guru PTK) memberikan bimbingan dan arahan. Setelah waktu yang diberikan untuk mengerjakan LKS telah habis,siswa perwakilan kelompok mempersentasikan hasil kerja kelompoknya dan kelompok lain menanggapi. Dalam kegiatan ini siswa mampu memahami dan menyelesaikansoal terkait bagian-bagian, sifat-sifat, serta jaringjaring prisma, dan limas.

Kegiatan peneliti (guru PTK) selanjutnya adalah melaksanakan kegiatan penutup.Pada kegiatan penutup ini peneliti (guru PTK) dan siswa membuat kesimpulan tentang materi yang baru saja dipelajari. Kemudian peneliti (guru PTK) meminta siswa untuk mempelajari luas permukaan prisma dan limas serta volumenya untuk pertemuan selanjutnya.Selama kegiatan pembelajaran berlangsung peneliti mengobservasi jalannya pembelajaran.

\section{Pertemuan 2}

Pertemuan II merupakan lanjutan dari pertemuan I yang dilaksanakan pada hari Kamis, 28 April 2016 dan materi yang diajarkan yaitu luas permukaan prisma dan limas serta volumenya. Pada pertemuan ini peneliti (guru PTK) kembali melaksanakan rencana pembelajaran dengan melaksanakan tindakan pendahuluan yakni menginformasikan materi yang dibahas, menyampaikan tujuan pembelajaran dan kompetensi dasar yang ingin dicapai serta menginformasikan kemampuan prasyarat yang dimiliki siswa.

Setelah dilakukan kegiatan pendahuluan peneliti (guru PTK) melaksanakan kegiatan inti yang sesuai dengan tujuan pembelajaran. Pembelajaran ini diikuti oleh 18 siswa dan dilaksanakan dengan cara diskusi kelompok. Kelompok pembelajarannya terdiri dari 4 kelompok yakni 2 kelompok terdiri dari 5 siswa dan 2 kelompok terdiri dari 4 siswa. Sebelum peneliti (guru PTK) menyajikan materi pelajaran guru menjelaskan kepada siswa tentang metode pembelajaran yang akan digunakan.

Pada kegiatan inti ini, peneliti (guru PTK) mengingatkan kembali pelajaran pertemuan I, kemudian menjelaskan materi tentang luas permukaan prisma dan limas serta volumenya. Setelah itu peneliti (guru PTK) membagikan siswa Lembar Kerja Siswa (LKS) mengenai luas permukaan prisma dan limas serta volumenya. Siswa mengerjakan LKS secara berkelompok. Pada saat pembelajaran berlangsung jika ada siswa yang mengalami kesulitan maka peneliti (guru PTK) memberikan bimbingan dan arahan.Setelah waktu yang diberikan untuk mengerjakan LKS telah habis,siswa perwakilan kelompok mempersentasikan hasil kerja kelompoknya dan kelompok lain menanggapi.Dalam kegiatan ini siswa mampu memahami dan menyelesaikansoal terkait luas permukaan prisma dan limas serta volumenya namun ada sebahagian siswa juga masih kesulitan dalam menyelesaikan soal.

Kegiatan peneliti (guru PTK) selanjutnya adalah melaksanakan kegiatan penutup. Pada kegiatan penutup ini peneliti (guru PTK) dan siswa membuat kesimpulan tentang materi yang baru saja dipelajari. Selama kegiatan pembelajaran berlangsung peneliti mengobservasi jalannya pembelajaran.

\section{Observasi/Evaluasi}

Pada proses pelaksanaan observasi dilakukan bersamaan dengan proses pelaksanaan tindakan pada siklus I berlangsung. Pembelajaran melalui pendekatan Contextual Teaching and Learning (CTL)merupakan pembelajaran yang masih asing bagi siswa dikarenakan pendekatan 
Azis, Nining Nurbianti K.

pembelajaran tersebut belum pernah diterapkan kepada siswa.

Hal-hal yang diobservasi pada pelaksanaan tindakan ini adalah kegiatan guru dan siswa selama proses pembelajaran berlangsung. Pada pembelajaran siklus I pertemuan I guru tidak menyampaikan tujuan pembelajaran dan ketika guru menjelaskan langkah-langkah pembelajaran CTL sebagian siswa tidak memperhatikan sehingga ada siswa yang masih bingung dengan metode pembelajaran yang dilaksanakan. Pada saat pembuatan soal dan menyelesaikan soal dalam kelompok ada beberapa orang siswa yang mengharapkan jawaban dari teman kelompoknya. Dalam mempresentasekan hasil kerja kelompok, guru membimbing semua kelompok, peneliti (guru PTK) tidak merangkum materi yang telah dibahas tetapi memberikan tugas untuk dikerjakan dirumah sebagai latihan siswa. Kemudian pada siklus I pertemuan II gurumenyampaikan tujuan pembelajaran dan ketika guru menjelaskan langkah-langkah pembelajaran CTL sebagian siswa tidak memperhatikan. Pada saat pembuatan soal dan menyelesaikan soal dalam kelompok ada beberapa orang siswa yang mengharapkan jawaban dari teman kelompoknya. Dalam mempresentasekan hasil kerja kelompok, guru membimbing semua kelompok, peneliti (guru PTK) merangkum materi yang telah dibahas dan tidak memberikan tugas untuk dikerjakan dirumah sebagai latihan siswa karena waktunya selesai.

Setelah pelaksanaan tindakan sebanyak dua kali pertemuan pada siklus I, dilakukan tes evaluasi untuk mengetahui hasil belajar siswa setelah diterapkannya pembelajaran CTL pada siklus I. Evaluasi dilakukan tanpa pembagian kelompok lagi karena akan dilihat hasil belajar siswa secara individu.

Berdasarkan analisis terhadap hasil observasi aktivitas guru dan siswa selama proses pembelajaran, diperoleh aktivitas guru dalam pembelajaran siklus I pertemuan pertama sebesar $57,14 \%$ dan pada pertemuan kedua sebesar $78,57 \%$ dengan rata-rata $67,68 \%$. Sedangkan aktivitas siswa dalam proses pembelajaran sebesar $50 \%$ pada pertemuan pertama dan $75 \%$ pada pertemuan kedua dengan rata-rata $62,5 \%$. Hasil-hasil ini menunjukkan bahwa pelaksanaan pembelajaran oleh guru belum maksimal sehingga aktivitas siswa dalam pembelajaran juga rendah. Selain itu siswa baru mengenal model pembelajaran CTL sehingga dalam proses pembelajaran siswa kurang maksimal.
Tabel 2. Rekapitulasi Hasil Observasi Aktivitas Guru dan Siswa Pada Siklus I

\begin{tabular}{ccc}
\hline Pertemuan & \multicolumn{2}{c}{ Persentase } \\
ke- & Gutivitas \\
\cline { 2 - 3 } & Suru & Siswa \\
\hline Pertama & 57,14 & 50 \\
Kedua & 78,57 & 75 \\
Rata-Rata & 67,85 & 62,5 \\
\hline
\end{tabular}

Adapunhasil tes siklus I, dari 18 siswa memperoleh nilai dengan rata-rata 52,5 dengan siswa yang memperoleh nilai $\geq 60$ sebanyak 9 siswa dan yang memperoleh nilai < 60 sebanyak 9 siswa serta ketuntasan belajar klasikal sebesar $50 \%$. Siswa yang memperoleh nilai maksimum adalah75dan yang memperoleh nilai minimum adalah30 dengan nilai ideal adalah 100.Tampak bahwa rata-rata kemampuan tes siklus I belum mencapai batas ketuntasan yang ditetapkan oleh sekolah yaitu 60, namun perlu ditingkatkan.

Tabel 3. Rekapitulasi Prestasi Belajar Siswa Pada Siklus I

\begin{tabular}{cccc}
\hline Indikator & Kategori & $\begin{array}{c}\text { Banyak } \\
\text { Siswa }\end{array}$ & Persentase \\
\hline $\mathrm{N} \geq 60$ & Tuntas & 9 & $50 \%$ \\
$\mathrm{~N}<60$ & $\begin{array}{c}\text { Tidak } \\
\text { tuntas }\end{array}$ & 9 & $50 \%$ \\
\hline
\end{tabular}

\section{Refleksi}

Pada tahap ini, peneliti bersama guru secara kolaboratif menilai dan mendiskusikan kelemahan-kelemahan dan kekurangankekurangan yang terdapat pada pelaksanaan tindakan siklus I untuk kemudian diperbaiki dan dilaksanakan pada tindakan siklus II.

Berdasarkan hasil observasi dan evaluasi diperoleh informasi bahwa proses pembelajaran pada siklus I kurang maksimal disebabkan karena masih banyak siswa yang bingung dengan proses pembelajaran melalui pendekatan Contextual Teaching and Learning (CTL). Hal ini terlihat dari sedikitnya siswa yang mampu menyampaikan pendapatnya di depan kelas. Siswa belum memanfaatkan betul kerjasama dalam kelompok. Ini terbukti dari hasil tes tindakan siklus I masih banyak siswa yang nilainya dibawah 60 .

Ketergantungan siswa terhadap sumber pelajaran yang berasal dari guru atau sekolah, menyebabkan siswa kurang memahami secara baik materi yang telah diajarkan.Siswa kurang termotivasi untuk belajar, sehingga mereka enggan untuk bertanya ketika mendapat 
Azis, Nining Nurbianti K.

kesulitan.Dilain pihak, guru terkadang terlena dalam memberikan bimbingan terhadap satu siswa sehingga siswa yang lain terabaikan.

Dengan melihat banyaknya kekurangankekurangan yang ada, serta prestasi belajar matematika siswa yang belum maksimal, sehingga proses penelitian ini dilanjutkan pada siklus II dengan memperbaiki kekurangankekurangan yang terjadi pada siklus I.

Siklus II

\section{Tahap Pendahuluan}

Dalam siklus II ini direncanakan dapat meningkatkan prestasi belajar siswa yang ratarata hasil belajarnya masih belum cukup memuaskan pada proses siklus I. Pada proses siklus II juga ini pembelajaran dilakukan dengan pendekatan Contextual Teaching and Learning (CTL). Hal-hal yang dipersiapkan pada saat pelaksanaan tindakan siklus IIadalah sebagai berikut: 1) Menyiapkan rencana pembelajaran untuk pelaksanaan tindakan siklus II; 2) Menyiapkan lembar pengamatan (observasi) terhadap guru dan siswa; 3) Menyiapkan alat bantu mengajar; 4) Menyiapkan lembar kertas kerja; dan 5) Menyiapkan alat evaluasi.

Dalam proses pembelajaran metode CTL berlangsung, siswa dibagi dalam beberapa kelompok untuk saling berdiskusi dalam menyelesaikan soal yang telah disediakan oleh peneliti (guru PTK) dan diharapkan setiap siswa aktif dan kreatif untuk mendapatkan hasil yang terbaik. Pembagian kelompok dibagi sesuai dengan tingkat kemampuan siswa yang berbedabeda.

\section{Tahap Tindakan}

Pelaksanaan tindakan pada siklus II dilaksanakan pada hari Rabu, 18 Mei 2016 dan materi yang diajarkan yaitu membahas soal-soal luas permukaan prisma dan limas serta volumenya yang bertujuan agar siswa lebih paham dalam pengerjaan soal-soal luas permukaan prisma dan limas serta volumenya. Guru memberikan pembelajaran sesuai dengan rencana pembelajaran dengan pendekatan Contextual Teaching and Learning (CTL) yang telah dibuat. Pada pelaksanaan pembelajaran siklus II ini dalam proses awal pembelajaran, guru menyampaikan tujuan pembelajaran yang nantinya akan dicapai oleh siswa serta memotivasi siswa agar dapat melakukan proses pembelajaran dengan baik.
Pada proses selanjutnya guru menyajikan materi kemudian memberikan beberapa contoh soal yang berhubungan dengan materi yang disajikan. Pembelajaran ini diikuti oleh 18 siswa dan dilaksanakan dengan cara diskusi kelompok. Kelompok pembelajarannya terdiri dari 4 kelompok yakni 2 kelompok terdiri dari 5 siswa dan 2 kelompok terdiri dari 4 siswa. Sebelum peneliti (guru PTK) menyajikan materi pelajaran guru menjelaskan kepada siswa tentang metode pembelajaran yang akan digunakan.

Pada kegiatan inti ini, peneliti (guru PTK) mengingatkan kembali pelajaran pertemuan II siklus I, kemudian mengingatkan kembali materi tentang luas permukaan prisma dan limas serta volumenya. Setelah itu peneliti (guru PTK) membagikan siswa Lembar Kerja Siswa (LKS) mengenai luas permukaan prisma dan limas serta volumenya. Siswa mengerjakan LKS secara berkelompok. Pada saat pembelajaran berlangsung jika ada siswa yang mengalami kesulitan maka peneliti (guru PTK) memberikan bimbingan dan arahan. Setelah waktu yang diberikan untuk mengerjakan LKS telah habis, siswa perwakilan kelompok mempersentasikan hasil kerja kelompoknya dan kelompok lain menanggapi. Dalam kegiatan ini siswa mampu memahami dan menyelesaikansoal terkait luas permukaan prisma dan limas serta volumenya namun ada sebahagian siswa juga masih kesulitan dalam menyelesaikan soal.

Kegiatan peneliti (guru PTK) selanjutnya adalah melaksanakan kegiatan penutup.Pada kegiatan penutup ini peneliti (guru PTK) dan siswa membuat kesimpulan tentang materi yang baru saja dipelajari. Selama kegiatan pembelajaran berlangsung peneliti mengobservasi jalannya pembelajaran.

\section{Observasi/Evaluasi}

Proses pelaksanaan observasi dilakukan bersamaan dengan proses pelaksanaan tindakan berlangsung. Hal-hal yang diobservasi pada tindakan ini adalah kegiatan guru dan siswa selama proses pembelajaran. Pada saat berlangsungnya proses pembelajaran siklus II ini guru melakukan proses pembelajaran sesuai dengan rencana pelaksanaan pembelajaran. Pada siklus II ini siswa sudah mulai dapat melakukan langkah-langkah pembelajaran dengan pendekatan Contextual Teaching and Learning (CTL) sehingga menunjukkan bahwa pelaksanaan tindakan siklus II sudah maksimal. Pada akhir proses pelaksanaan pembelajaran maka dilakukan tindakan pemberian tes kepada 
Azis, Nining Nurbianti K.

siswa untuk mengetahui tingkat kemampuan siswa selama proses pembelajaran berlangsung.

Berdasarkan analisis terhadap hasil observasi aktivitas guru dan siswa selama proses pembelajaran siklus II yang hanya 1 kali pertemuan, diperoleh aktivitas guru dalam pembelajaran siklus II sebesar 92,86\%. Sedangkan aktivitas siswa dalam proses pembelajaran sebesar 91,67\%. Hasil-hasil ini menunjukkan bahwa pelaksanaan pembelajaran oleh guru sudah maksimal.

Tabel 4. Rekapitulasi Hasil Observasi Aktivitas Guru dan Siswa Pada Siklus II

\begin{tabular}{ccc}
\hline \multirow{2}{*}{ Pertemuan ke- } & \multicolumn{2}{c}{ Persentase Aktivitas } \\
\cline { 2 - 3 } & Guru & Siswa \\
\hline Pertama & 92,86 & 91,67 \\
Rata-Rata & 92,86 & 91,67 \\
\hline
\end{tabular}

Adapun hasil tes siklus II, dari 18 siswa memperoleh nilai dengan rata-rata 79,44 dengan siswa yang memperoleh nilai $\geq 60$ sebanyak 18 siswa dan tidak ada siswa yang memperoleh nilai < 60 sehingga ketuntasan belajar klasikal sebesar $100 \%$, yang memperoleh nilai maksimal adalah 95 dan yang memperoleh nilai minimal adalah 60 dengan nilai ideal 100. Tampak bahwa rata-rata pada tes hasil siklus II, sudah mencapai batas ketuntasan yang ditetapkan oleh sekolah yaitu 60 .

Tabel 5. Rekapitulasi Prestasi Belajar Siswa Pada Siklus II

\begin{tabular}{cccc}
\hline Indikator & Kategori & $\begin{array}{c}\text { Banyak } \\
\text { Siswa }\end{array}$ & Persentase \\
\hline $\mathrm{N} \geq 60$ & Tuntas & 18 & $100 \%$ \\
$\mathrm{~N}<60$ & $\begin{array}{c}\text { Tidak } \\
\text { tuntas }\end{array}$ & 0 & 0 \\
\hline
\end{tabular}

\section{Refleksi}

Dari kegiatan yang dilaksanakan pada tindakan siklus II, sudah menunjukkan hasil memuaskan.Hal ini terlihat dari bertambahnya siswa yang aktif dari pertemuan ke pertemuan.Ini berarti siswa sudah mempunyai motivasi untuk belajar yang cukup baik terhadap pelajaran matematika.

Bertitik tolak pada hasil yang diperoleh pada tindakan siklus II, maka penelitian ini dihentikan sampai pada tindakan siklus II.Hal ini ditunjukkan dengan adanya keberhasilan siswa yang mampu memperoleh nilai $\geq 60$ dan juga adanya peningkatan prestasi belajar siswa dari siklus I ke siklus II. Dengan demikian, dapat menjawab hipotesis dalam penelitian ini yakni prestasi belajar siswa kelas VIII-F SMP Negeri 3 Baubau pada materi Bangun Ruang Sisi Datar dapat meningkat melalui pendekatan Contextual Teaching and Learning (CTL).

\section{Pembahasan}

Penelitian ini adalah penelitian tindakan kelas yang terdiri dari dua siklus.Siklus pertama terdiri dari dua kali pertemuan, pertemuan pertama dan kedua adalah memberikan dan menjelaskan materi yang dilaksanakan sesuai dengan prosedur penelitian. Sedangkan siklus kedua terdiri dari satu kali pertemuan untuk memberikan dan menjelaskan materi yang dilaksanakan sesuai dengan prosedur penelitian. Pada penelitian ini peneliti dan guru berkolaborasi. Dalam hal ini guru bertindak sebagai pengajar yakni guru memberikan penjelasan materi dan peneliti yang membantu dalam menampilkan materi dengan pendekatan pembelajaran Contextual Teaching and Learning (CTL) sekaligus peneliti bertindak sebagai observator.

Pembentukan kelompok dalam penelitian ini sudah dilakukan sebagaimana mestinya.Siswa dibagi dalam 4 kelompok, dimana masingmasing kelompok dibentuk secara heterogen. Karena jumlah siswa kelas VIII-F SMP Negeri 3 Baubau sebanyak 18 orang maka banyaknya kelompok dibagi menjadi 4 kelompok dimana setiap kelompok terdiri dari 4 atau 5 orang siswa.

Berdasarkan hasil observasi aktivitas guru dan siswa selama proses pembelajaran siklus I yang terdiri dari 2 kali pertemuan yaitu pada pertemuan pertama diperoleh persentase aktivitas guru sebesar $57,14 \%$ dan pada pertemuan kedua sebesar $78,57 \%$. Sehingga rata-rata persentase aktivitas guru pada siklus I sebesar 67,85\%. Sedangkan pertemuan pertama siklus I persentase aktivitas siswa sebesar 50\% dan $75 \%$ merupakan persentase aktivitas siswa pertemuan kedua dengan memperoleh rata-rata sebesar $62,5 \%$. Selanjutnya hasil observasi yang dilakukan pada siklus II yang hanya 1 kali pertemuan, persentase aktivitas guru sebesar $92,86 \%$ dan persentase aktivitas siswa sebesar 91,67\%.

Adapun hasil evaluasi yang dilakukan pada siklus I terlihat adanya peningkatan prestasi belajar matematika siswa setelah diterapkan pendekatan pembelajaran Contextual Teaching and Learning (CTL). Pada tes awal, 6 siswa atau sebesar 33,33\% memperoleh nilai $\geq 60$ dengan nilai rata-rata 50 sedangkan hasil tes tindakan siklus I menunjukkan bahwa 50\% (9 siswa) 
Azis, Nining Nurbianti K.

memperoleh nilai $\geq 60$ dengan nilai rata-rata 52,5. Hal ini menunjukkan bahwa pemahaman siswa meningkat sebesar $16,67 \%$ (3 siswa).

Beritik tolak dari kekurangan-kekurangan yang masih ada serta hasil belajar matematika siswa pada tindakan siklus I yang belum memenuhi kriteria ketuntasan belajar dalam penelitian ini, maka penelitian ini dilanjutkan pada tindakan siklus II.Pada siklus II pendekatan pembelajaran Contextual Teaching and Learning (CTL)kembali dilaksanakan.

Hasil observasi pada siklus II menunjukkan bahwa guru dan siswa telah melakukan kegiatan pembelajaran sesuai dengan yang diharapkan. Kekurangan-kekurangan yang terjadi pada siklus I sudah dapat diperbaiki. Guru sudah mampu mengefektifkan pemantauan dan bimbingan terhadap siswa. Di samping itu, siswa sudah terlihat aktif dalam mengikuti kegiatan pembelajaran.

Selanjutnya hasil eveluasi yang dilakukan pada siklus II, siswa yang memperoleh nilai $\geq 60$ sebanyak 18 orang atau sebesar $100 \%$ dengan nilai rata-rata 79,44. Ini menunjukkan bahwa terjadi peningkatan dari hasil tes tindakan siklus I ke hasil tes tindakan siklus II yaitu sebesar 50\% (9 siswa).

Dari hasil tes evaluasi siswa yang diperoleh pada siklus II, dapat dikatakan bahwa pendekatan pembelajaran Contextual Teaching and Learning (CTL)memberikan dampak positif terhadap prestasi belajar siswa.Nilai mereka meningkat dan sudah mampu mengeluarkan pendapatnya serta menjawab pertanyaan yang diberikan. Kriteria ketuntasan belajar klasikal dalam penelitian ini telah tercapai, dalam hal ini terjadi peningkatan prestasi belajar siswa dari siklus I ke siklus II maka penelitian dihentikan sampai pada siklus II. Dengan demikian maka hipotesis telah terjawab yaitu prestasi belajar siswa kelas VIII-F SMP Negeri 3 Baubau pada materi Bangun Ruang Sisi Datar dapat meningkat melalui pendekatan Contextual Teaching and Learning (CTL).

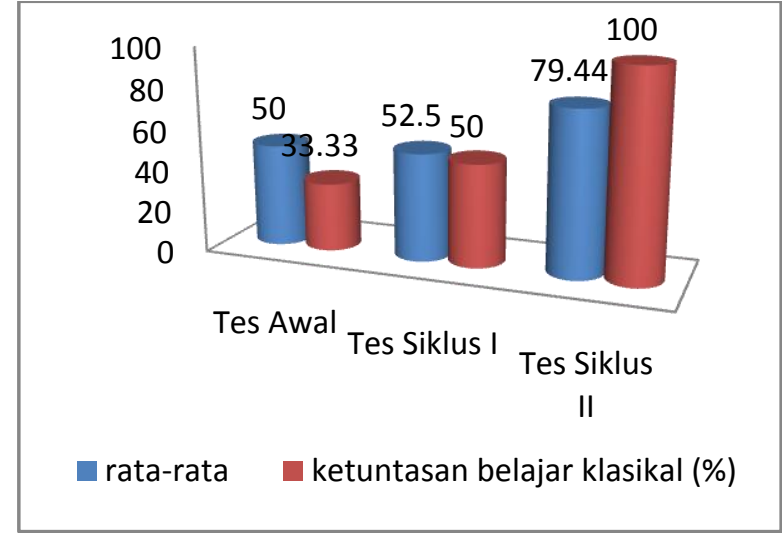

Gambar 2. Grafik Peningkatan Prestasi Belajar Siswa Secara Keseluruhan

Tabel 6. Rekapitulasi Prestasi Belajar SiswaDari Tes Awal Hingga Siklus II

\begin{tabular}{cccccccc}
\hline \multirow{2}{*}{ No. Kategori } & \multirow{2}{*}{ Tes } & \multirow{2}{*}{ Persen } & Siklus & \multicolumn{3}{c}{ Piklus } & \multirow{2}{*}{ Persen } \\
& Awal & & I & & II & Persen \\
\hline 1 & Tuntas & 6 & 33,33 & 9 & 50 & 18 & 100 \\
2 & $\begin{array}{c}\text { Tidak } \\
\text { Tuntas }\end{array}$ & 12 & 66,67 & 9 & 50 & 0 & 0 \\
\hline Jumlah & 18 & 100 & 18 & 100 & 18 & 100 \\
\hline
\end{tabular}

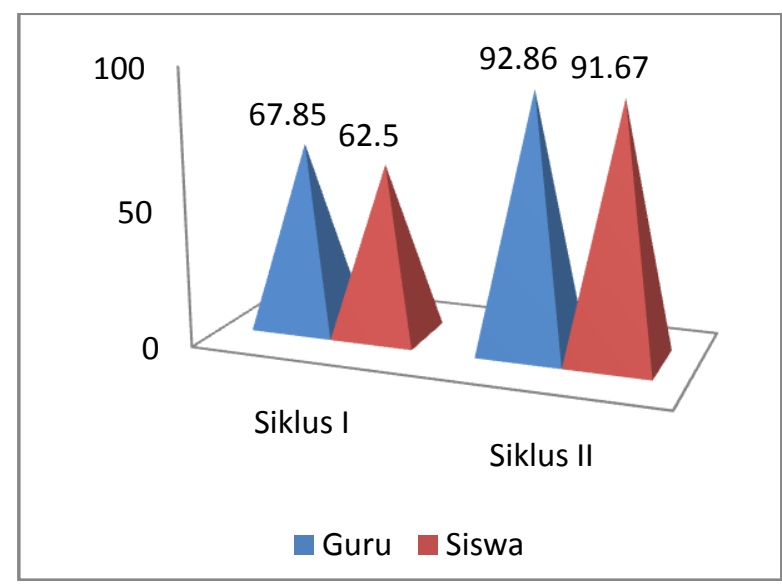

Gambar 3. Grafik Peningkatan Aktivitas Guru Dan Siswa Secara Keseluruhan

Tabel 7. Rekapitulasi Observasi Guru Dan Siswa Pada Siklus I Dan Siklus II

\begin{tabular}{ccc}
\hline \multirow{2}{*}{ Siklus } & \multicolumn{2}{c}{ Persentase Aktivitas } \\
\cline { 2 - 3 } I & Guru & Siswa \\
II & 67,86 & 62,5 \\
& 92,86 & 91,67 \\
\hline
\end{tabular}


Azis, Nining Nurbianti K.

\section{KESIMPULAN DAN SARAN}

\section{Kesimpulan}

Berdasarkan hasil penelitian yang telah disajikan dan dibahas pada BAB IV, dapat disimpulkan bahwa prestasi belajar siswa kelas VIII-F SMP Negeri 3 Baubau pada materi Bangun Ruang Sisi Datar dapat meningkat melalui pendekatan Contextual Teaching and Learning (CTL).

\section{Saran}

Berdasarkan hasil penelitian dan kesimpulan, penulis menyarankan: 1) Bagi sekolah khususnya SMP Negeri 3 Baubau bahwa pembelajaran dengan pendekatan Contextual Teaching and Learning (CTL) dapat dijadikan sebagai salah satu alternatif dalam meningkatkan prestasi belajar siswa dalam bidang studi matematika khususnya pada pokokbahasan Bangun Ruang Sisi Datar; 2) Pendekatan Contextual Teaching and Learning (CTL) dapat lebih sering diterapkan bukan hanya pada mata pelajaran matematika tetapi juga mata pelajaran lain; dan 3) Siswa sekiranya dapat lebih fokus memperhatikan pelajaran ketika proses belajar mengajar berlangsung.

\section{DAFTAR PUSTAKA}

[1] Abduh. 2007. Pendekatan Pembelajaran Kontekstual: Sebuah Strategi Belajar Dalam Pembelajaran Inovatif. (Naskah disajikan dalm seminar Peningkatan kualitas penyelenggaraan PPL Mahasiswa S1 PGSD, di Universitas UNM, Makassar, $10-$ 12 November 2007).

[2] Abdurrahman, M. 1999. Pendidikan Bagi Anak Berkesulitan Belajar. Jakarta: Rineka Cipta.

[3] Aisyah. 2006. Pengembangan Pembelajaran Matematika SD. Jakarta: Depdiknas.

[4] Antonius. 2006. Pemahaman dan penyajian konsep matematika secara benar dan menarik. Jakarta: Depdiknas Direktorat Jendral pendidikan tinggi direktorat ketenagaan.

[5] Arikunto, S. 2007. Penelitian Tindakan Kelas. Jakarta: Bumi Aksara.

[6] Aunurrahman. 2011. Belajar dan Pembelajaran. Bandung: Alfabeta.
[7] Darhim. 1992. Work Shop Matematika. Jakarta: Depdikbud.

[8] Depdiknas. 2003. Undang-Undang Republik Indonesia Nomor 2, Tahun 2003, tentang Sistem Pendidikan Nasional.

[9] Hamzah. 2010. Mengelola Keceradasan Dalam Pembelajaran. Jakarta: Bumi Aksara.

[10] Hudoyo, H. 1988. Pengembangan Kurikulum Matematika dan Pelaksanannya di Depan Kelas. Surabaya: Usaha Nasional.

[11] Kulsum. 2011. Implementasi Pendidikan Berkarakter Berbasis Paikem. Surabaya: Gena Pratama Pustaka.

[12] Muchitch. 2008. Pembelajaran Kontekstual. Semarang: Rasail Media Group.

[13] Muliati. 2000. Pembelajaran Matematika. Bandung: Alfabeta.

[14] Nurhadi. 2003. Pembelajaran Kotekstual dan Penerapannya dalam KBK. Malang: Universitas Negeri Malang.

[15] Pelita. 2002. Meningkatkan Pemahaman Siswa dalam Pengajaran Bangun Ruang Dengan Menggunakan Alat Peraga. Skripsi. Kendari: Universitas Haluoleo.

[16] Purwanto. 1991. Psikologi Belajar. Jakarta: Rineka Cipta.

[17] Ruseffendi, E.T. 1992. Dasar-Dasar Matematika Modern Untuk Guru. Bandung: Tarsito.

[18] Suparno. 2008. Riset Tindakan Untuk Pendidik. Jakarta: Grasindo.

[19] Susilo, J.M. 2004. Dasar-Dasar dan Proses Pembelajaran. Yogyakarta: LP2I Press.

[20] Taniredja. 2011. Model-Model Pembelajaran Inovatif. Bandung: Alfabeta.

[21] Thobroni. 2011. Belajar dan Pembelajaran. Jakarta: Ar-Ruz Media.

[22] Usman. 1994. Upaya Optimalisasi Kegiatan Belajar Mengajar. Bandung: Remaja Rosdakarya. 